\title{
A balanced water layer concept for subglacial hydrology in large-scale ice sheet models
}

\author{
S. Goeller, M. Thoma, K. Grosfeld, and H. Miller \\ Alfred Wegener Institute, Helmholtz Centre for Polar and Marine Research, Am Alten Hafen 26, \\ 27568 Bremerhaven, Germany
}

Correspondence to: S. Goeller (sebastian.goeller@awi.de)

Received: 31 August 2012 - Published in The Cryosphere Discuss.: 17 December 2012

Revised: 6 June 2013 - Accepted: 7 June 2013 - Published: 13 July 2013

\begin{abstract}
There is currently no doubt about the existence of a widespread hydrological network under the Antarctic Ice Sheet, which lubricates the ice base and thus leads to increased ice velocities. Consequently, ice models should incorporate basal hydrology to obtain meaningful results for future ice dynamics and their contribution to global sea level rise. Here, we introduce the balanced water layer concept, covering two prominent subglacial hydrological features for ice sheet modeling on a continental scale: the evolution of subglacial lakes and balance water fluxes. We couple it to the thermomechanical ice-flow model RIMBAY and apply it to a synthetic model domain. In our experiments we demonstrate the dynamic generation of subglacial lakes and their impact on the velocity field of the overlaying ice sheet, resulting in a negative ice mass balance. Furthermore, we introduce an elementary parametrization of the water flux-basal sliding coupling and reveal the predominance of the ice loss through the resulting ice streams against the stabilizing influence of less hydrologically active areas. We point out that established balance flux schemes quantify these effects only partially as their ability to store subglacial water is lacking.
\end{abstract}

\section{Introduction}

Hundreds of subglacial lakes have been identified underneath the Antarctic Ice Sheet within the last decade (Siegert et al., 2005; Smith et al., 2009; Wright and Siegert, 2011). Observations also indicate interactions between lakes over several hundred kilometers (Wingham et al., 2006; Fricker et al., 2007, 2010; Fricker and Scambos, 2009) and thus reveal that these lakes are not isolated, but can belong to distinct subglacial hydrological networks. Basal water lubricates the base of the ice sheet locally and hence leads to a reduced basal drag of the overlaying ice. As a result, fast flowing ice streams can evolve above areas of enhanced subglacial water flow, and the ice velocity increases over subglacial lakes (Bell et al., 2007). Increased ice velocities affect the mass balance of the Antarctic Ice Sheet and thus might have a considerable impact on global sea level rise. Consequently, it is a necessity to incorporate basal hydrology into ice sheet models as it is considered to be one of the key parameters required to achieve more realistic results with respect to climate prediction (IPCC, 2007).

Despite the very low surface temperatures, large areas of the bed of the Antarctic Ice Sheet are at the pressure melting point, actively melting through the combined influence of the insulating ice cover and the geothermal heat flux into the base of the ice sheet. Model results show that around $55 \%$ of the Antarctic Ice Sheet base could produce melt water, while the rest of the ice sheet might be frozen to the bedrock (Pattyn, 2010).

For the transport of melt water there are two fundamental water flow regimes: channelized and distributed. Channelized systems are spatially concentrated and transport large volumes of water at high effective pressure (ice overburden pressure minus water pressure), whereby the effective pressure increases with increasing water flux. Examples of channelized systems include Roethlisberger channels incised into the ice base (Roethlisberger, 1972) and Nye channels cut into bedrock (Nye, 1973). Channelized systems act to reduce slip by drawing water from off-axis flow and increasing coupling there. Their net effect is to reduce ice slip and thus ice discharge. 
Distributed systems are laterally extensive and transport a small volume of water at low effective pressure. Examples include systems of linked cavities, which emerge by the ice flowing over bedrock bumps (Lliboutry, 1968); flow through a water film between ice and bedrock (Weertman, 1972); flow in canals eroded into sediment (Walder and Fowler, 1994); and flow within groundwater and till (Alley et al., 1986). Because effective pressure decreases with increasing water flux, these systems tend to enhance slip along the ice-bed interface.

In general, the basal water flux follows the gradient of the hydraulic potential (Shreve, 1972), which includes both the water pressure and the bedrock elevation. However, the governing flow regime itself depends very much on the local geological properties at the ice base. They might range from solid bedrock, rough debris and till, to soft sediments. For the Antarctic Ice Sheet these very important basal conditions are only known from a very sparse number of boreholes. Thus, they are basically unknown for the majority of the Antarctic continent as the ice sheet base has been quite inaccessible for direct observations thus far.

Nevertheless, promising efforts have been made recently to gain a collocated mathematical description for distributed and channelized water flow systems (Schoof, 2010; Schoof et al., 2012; Hewitt, 2011; Hewitt et al., 2012). They are well implementable for the modeling of small mountain glaciers where high-resolution data sets of the order of hundreds of meters for ice thickness and bedrock elevation exist. However, for larger ice sheets or even continental-scale modeling their application is limited, since the geological properties of the bedrock are unknown and the available database is too coarse. Locally, numerous airborne campaigns in Antarctica (e.g., IceBridge, IceCap, IceGrav) make high-resolution bedrock digital elevation models available. But for the whole Antarctic Ice Sheet typical elevation models provide the required geophysical data on a 1 to $5 \mathrm{~km}$ grid scale (Le Brocq et al., 2010; Fretwell et al., 2013), and still large areas of the bedrock are interpolated. Describing channelized water flux between adjacent grid cells at these scales would require the assumption of an appropriate channel density or modeling the hydrology at higher resolution than the bedrock topography data available and thus facing major computational costs.

Another well-established method to trace the paths of subglacial melt water is the balance flux concept (Quinn et al., 1991; Budd and Warner, 1996; Tarboton, 1997; Le Brocq et al., 2006, 2009). The concept is easy to implement, fast and well applicable to continental-scale modeling (e.g., Pattyn, 2010). The approach makes the assumption that the water pressure is equal to the overburden ice pressure and thus only includes distributed flow. It presumes a basal hydraulic system in steady state and delivers the associated water flux for every grid cell, but it is unable to describe water pressures. Another disadvantage of this attempt to describe basal hydrology is the lacking mass conservation on realistic topographies: only a fraction of the melt water produced inside the model domain reaches its margins, because upstream flux contributions are lost at local minima of the hydropotential surface. Additional computational effort is necessary to conserve the flux over these hollows. Furthermore, the balance flux concept provides no possibility for melt water to accumulate in hollows and to form subglacial lakes. This is of major importance for ice modeling since basal shear vanishes over lakes, which clearly affects the ice sheet dynamics (Pattyn et al., 2004; Thoma et al., 2010, 2012).

To transfer the advantages of the balance flux concept and to overcome its weaknesses, we introduce the balanced water layer concept. This new approach assumes a distributed flow regime and is fully mass conservative on any topography without the necessity of any additional modifications. For inclined regions of the hydraulic potential it yields the balance flux. In addition, this concept allows water to accumulate in hollows of the hydraulic potential and hence to form subglacial lakes. Once lakes are filled to their maximum level, melt water generated upstream flows through the lakes to their discharge point and thus contributes to downstream flow.

In this paper we describe the new balanced water layer concept and couple it to the thermomechanical ice model RIMBAY (Thoma et al., 2010, 2012, 2013; Determann et al., 2012). The benefits of our new approach are demonstrated in the application to a synthetic model domain and the comparison with the original balance flux concept. We use an elementary parametrization of the sliding law to simplify the complex interaction between ice dynamics and basal hydrology and show their crucial impact on ice sheet dynamics and mass balance.

\section{Balanced water layer concept}

\subsection{General formulation}

The melt water at the base of the ice sheet follows the gradient of the hydraulic potential $p$ (Shreve, 1972)

$p=\rho_{\mathrm{w}} g z+p_{\mathrm{w}}$,

with $\rho_{\mathrm{w}}$ as the water density, $g$ as the acceleration of the gravity and $p_{\mathrm{w}}$ as the water pressure at the considered point of elevation $z$. Assuming a distributed water flow system this expression can be simplified while stating that the effective pressure at the ice base (ice overburden pressure $p_{\mathrm{i}}$ minus water pressure $p_{\mathrm{w}}$ at the ice base) is close to zero (e.g., Budd and Jenssen, 1987; Alley, 1996). Under the approximation $p_{\mathrm{w}}=p_{\mathrm{i}}$ the hydraulic potential can be written as

$p=\rho_{\mathrm{w}} g z+p_{\mathrm{i}}$

with the ice pressure $p_{\mathrm{i}}=\rho_{\mathrm{i}} g H$, where $H$ is the ice thickness and $\rho_{\mathrm{i}}$ the ice density. Defining a water layer with thickness $W$ between the bedrock with elevation $B$ and the ice base, 
we obtain the hydraulic potential

$p=\rho_{\mathrm{w}} g(B+W)+\rho_{\mathrm{i}} g H$.

We convert Eq. (3) with $[p]=\mathrm{Pa}$ into the water equivalent hydraulic potential $P=p /\left(\rho_{\mathrm{w}} g\right)$ with $[P]=\mathrm{m}$ a.s.l. and reflect the fact that bedrock $B$, ice thickness $H$, water layer thickness $W$ and consequently the hydraulic potential $P$ are time-dependent in general, by adding a time index $t$.

$P^{t}=B^{t}+W^{t}+H^{t} \frac{\rho_{\mathrm{i}}}{\rho_{\mathrm{w}}}$

The balance equation for the evolution of the water layer $W^{t}$ is given by

$\frac{\partial W^{t}}{\partial t}=-\operatorname{div}\left(W^{t} \bar{v}^{(\mathrm{w})}\right)+M^{t}$

where $\bar{v}^{(\mathrm{w})}$ is the vertical averaged water velocity and $M^{t}$ is the melt rate. The values for bedrock elevation $B^{t}$, ice thickness $H^{t}$ and melt rate $M^{t}$ are provided by an ice model which is coupled to the hydrology model. Presuming that the water velocity is much higher than the ice velocity, the hydrology can be brought to an equilibrium state with the geometry (provided by the ice model) at every time step. Stating that the water velocity follows the gradient of the hydraulic potential, Eq. (5) can be solved iteratively: first the current water layer thickness $W^{t}$ is computed by adding the melt water input $M^{t} \cdot \Delta t$ to the water layer thickness $W^{t-1}$ of the previous time step. Then the available water is redistributed along the gradient of the hydraulic potential (Eq. 4) in an iterative way until a stationary basal water distribution $W^{t}$ is found.

This basic concept is applicable to all kinds of ice models, whether they use a finite difference, finite element or finite volume discretization. The ice model RIMBAY is based on finite differences. Consequently, we formulate the implementation of the hydrology model in finite differences, too, allowing a direct coupling of both models.

\subsection{Implementation for finite differences}

The potential $P_{i, j}^{t}$ for a grid cell $(i, j)$ at time step $t$ is composed of a constant part $P_{i, j}^{* t}=B_{i, j}^{t}+H_{i, j}^{t} \rho_{\mathrm{i}} / \rho_{\mathrm{w}}$ and the adjustable water layer thickness $W_{i, j}^{t}$, which has to be balanced out with respect to the potential $P_{i, j}^{t}$. The iteration is all done for time step $t$, so we omit the time index for reasons of clarity.

$P_{i, j}=P_{i, j}^{*}+W_{i, j}$

The balanced water layer concept operates on an Arakawa C-grid (Arakawa and Lamb, 1977). Hence the gradients of the hydraulic potential $P_{i, j}$ are defined at the margins of the grid cells as

$$
\frac{\partial P_{i, j}}{\partial x}=\frac{P_{i+1, j}-P_{i, j}}{\Delta x} \quad \text { and } \quad \frac{\partial P_{i, j}}{\partial y}=\frac{P_{i, j+1}-P_{i, j}}{\Delta y} .
$$

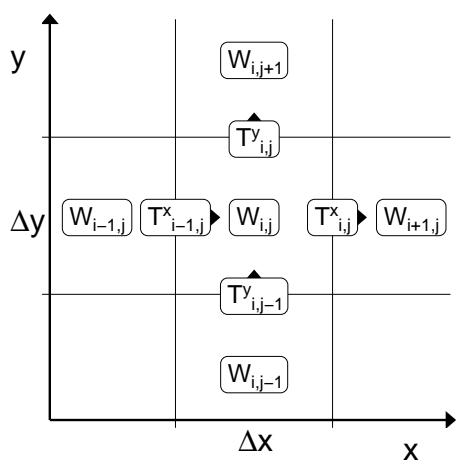

Fig. 1. Notation for staggered Arakawa C-grid: at the grid center: basal water layer thickness $W_{i, j}$, hydraulic potential $P_{i, j}$, normalization $N_{i, j}$, and water flux $\phi_{i, j}$ (for coupling to an A-grid ice model); at the grid cell edges: water transport $T_{i, j}^{x}$ and $T_{i, j}^{y}$, hydraulic gradients $\partial P_{i, j} / \partial x$ and $\partial P_{i, j} / \partial y$, and water flux $\phi_{i, j}^{x}$ and $\phi_{i, j}^{y}$ (for coupling to an C-grid ice model).

The instantaneous transport of water between adjacent grid cells for one iterative step is expressed by $T_{i, j}^{x}$ and $T_{i, j}^{y}$, where the sign gives the direction and the product with the grid size $\Delta x \Delta y$ the volume of the water transport (Fig. 1). To normalize all directional water transports out of a grid cell $(i, j)$ we introduce the norm $N_{i, j}$ with

$$
\begin{aligned}
N_{i, j} & =\max \left(\frac{\partial P_{i-1, j}}{\partial x}, 0\right)+\max \left(-\frac{\partial P_{i, j}}{\partial x}, 0\right) \\
& +\max \left(\frac{\partial P_{i, j-1}}{\partial y}, 0\right)+\max \left(-\frac{\partial P_{i, j}}{\partial y}, 0\right) .
\end{aligned}
$$

The differences of the potential between adjacent grid cells are defined as

$\Delta_{x} P_{i, j}=\left|P_{i+1, j}-P_{i, j}\right|$

$\Delta_{y} P_{i, j}=\left|P_{i, j+1}-P_{i, j}\right|$.

So the water transports $T_{i, j}^{x}$ and $T_{i, j}^{y}$ with $\left[T_{i, j}^{\mathrm{x} / \mathrm{y}}\right]=\mathrm{m}$ can be calculated for all grid cell edges by

$T_{i, j}^{x}=-\frac{\partial P_{i, j}}{\partial x}\left\{\begin{array}{cl}\frac{\min \left(W_{i, j}, \varepsilon \Delta_{x} P_{i, j}\right)}{N_{i, j}}, & \frac{\partial P_{i, j}}{\partial x}<0 \\ \frac{\min \left(W_{i+1, j}, \varepsilon \Delta_{x} P_{i, j}\right)}{N_{i+1, j}}, & \text { else }\end{array}\right.$

$T_{i, j}^{y}=-\frac{\partial P_{i, j}}{\partial y}\left\{\begin{array}{cl}\frac{\min \left(W_{i, j}, \varepsilon \Delta_{y} P_{i, j}\right)}{N_{i, j}}, & \frac{\partial P_{i, j}}{\partial y}<0 \\ \frac{\min \left(W_{i, j+1}, \varepsilon \Delta_{y} P_{i, j}\right)}{N_{i, j+1}}, & \text { else. }\end{array}\right.$

with the convergence parameter $\varepsilon \in(0,1)$. They are determined by the direction, the amount and the normalization of the water transfer. The sign of the hydraulic gradient (Eq. 7) 
gives the direction of the water transport in Eq. (10). The normalization is done by the ratio of the hydraulic gradient and $N_{i, j}$ of the water-contributing (upstream) grid cell. To achieve convergence, we transport a water amount corresponding to a fraction $\varepsilon$ of the differences of the potential (Eq. 9). These transferred amounts are bounded by the maximum available volume of water so that $\varepsilon \Delta_{x} P_{i, j}$ or $\varepsilon \Delta_{y} P_{i, j}$ will never exceed $W_{i, j}$.

Finally, we obtain the water layer for the next iteration step by

$W_{i, j}^{\text {(iter. }+1)}=W_{i, j}^{\text {(iter.) }}+T_{i-1, j}^{x}-T_{i, j}^{x}+T_{i, j-1}^{y}-T_{i, j}^{y}$

and start again at Eq. (6), until we find the change of the water layer thickness for all $n$ grid cells under a certain threshold $\Delta W^{\text {(threshold) }}$

$\frac{1}{n} \sum_{i, j}\left|W_{i, j}^{\text {(iter. }+1)}-W_{i, j}^{\text {(iter.) }}\right| \leq \Delta W^{\text {(threshold) }}$.

Here, the target precision of the basal water distribution rules the choice of $\Delta W^{\text {(threshold) }}$, where a smaller value leads to a better levelness of subglacial lake surfaces but needs further iterations.

Closed lateral boundary conditions for the balanced water layer concept (e.g., at ice-nunatak interfaces) can be easily implemented by setting the water transport to zero at the respective grid cell edges. Open lateral boundaries do not require a special treatment. However, one can sum up all outward water transports at these margins to yield a water flux in order to force another coupled model, e.g., an ocean model at ice-ocean interfaces.

\subsection{Scalar and vector water fluxes on $\mathrm{C}$ - and A-grids}

The scalar volume flux $Q$ with $[Q]=\mathrm{m}^{3} \mathrm{~s}^{-1}$ gives us the total water volume which is horizontally transferred between adjacent grid cells within time step $\Delta t$. On a C-grid we consequently obtain $Q_{i, j}^{x}$ and $Q_{i, j}^{y}$, which are defined at the grid cell edges. We compute the volume flux by adding up all instantaneous water transports (Eq. 10) during the above iteration:

$$
Q_{i, j}^{x}=\frac{\Delta x \Delta y}{\Delta t} \sum_{\text {iter. }} T_{i, j}^{x}, \quad Q_{i, j}^{y}=\frac{\Delta x \Delta y}{\Delta t} \sum_{\text {iter. }} T_{i, j}^{y} .
$$

As the volume flux (Eq. 13) between two grid cells can be considered to be orthogonal to the grid cell edges, we can derive directly the vector flux $\phi$ with $[\phi]=\mathrm{m}^{2} \mathrm{~s}^{-1}$ :

$\phi_{i, j}^{x}=\frac{Q_{i, j}^{x}}{\Delta y}, \quad \phi_{i, j}^{y}=\frac{Q_{i, j}^{y}}{\Delta x}$.

It is fairly simple to couple the water flux calculated by the balanced water layer concept to an ice model running on a $\mathrm{C}$-grid, because both water flux and ice velocities are determined at the edges of a grid cell.
Some more transformations are required if one wants to derive a scalar and vector water flux at the grid cell center for a coupling with an A-grid ice model. First we approximate the total volume flux $Q_{i, j}^{\text {(out) }}$ through a grid cell by the outflows $Q_{i, j}^{x}$ and $Q_{i, j}^{y}$ across the grid cell edges to

$$
\begin{aligned}
Q_{i, j}^{\text {(out) }} & =\max \left(-Q_{i-1, j}^{x}, 0\right)+\max \left(Q_{i, j}^{x}, 0\right) \\
& +\max \left(-Q_{i, j-1}^{y}, 0\right)+\max \left(Q_{i, j}^{y}, 0\right) .
\end{aligned}
$$

Then we determine the flux direction $\theta_{i, j}$ relative to the grid orientation by fitting a plane to the hydraulic potentials of the next four neighboring cells. According to Budd and Warner (1996) the vector flux $\phi_{i, j}$ at the center of a grid cell with side length $l=\Delta x=\Delta y$ is given by

$\phi_{i, j}=\frac{Q_{i, j}^{\text {(out) }}}{l\left(\left|\cos \theta_{i, j}\right|+\left|\sin \theta_{i, j}\right|\right)}$.

This balance vector flux $\phi_{i, j}$ is the steady-state solution of the water balance Eq. (5) with $\operatorname{div} \phi_{i, j}=M_{i, j}$.

\section{Ice model and coupling to hydrology}

In the present model study the three-dimensional thermomechanical finite differences ice-flow model RIMBAY is applied in shelfy-stream approximation (SSA) mode (e.g., MacAyeal, 1989; Pattyn, 2010; Thoma et al., 2013):

$$
\begin{aligned}
& \frac{\partial}{\partial x}\left[2 H \eta\left(2 \frac{\partial U}{\partial x}+\frac{\partial V}{\partial y}\right)\right]+\frac{\partial}{\partial y}\left[2 H \eta\left(\frac{\partial U}{\partial y}+\frac{\partial V}{\partial x}\right)\right] \\
& -\tau_{b x}=\rho_{\mathrm{i}} g H \frac{\partial S}{\partial x} \\
& \frac{\partial}{\partial y}\left[2 H \eta\left(2 \frac{\partial V}{\partial y}+\frac{\partial U}{\partial x}\right)\right]+\frac{\partial}{\partial x}\left[2 H \eta\left(\frac{\partial U}{\partial y}+\frac{\partial V}{\partial x}\right)\right] \\
& -\tau_{b y}=\rho_{\mathrm{i}} g H \frac{\partial S}{\partial y},
\end{aligned}
$$

with ice thickness $H$, temperature-dependent viscosity $\eta$, ice surface elevation $S$, the vertically integrated ice velocities $U$ and $V$, the basal shear stresses $\tau_{b x}$ and $\tau_{b y}$, the density of ice $\rho_{\mathrm{i}}$ and the gravitational acceleration $g$. We choose the shelfy-stream approach instead of the shallow-ice approximation (SIA) for grounded ice to incorporate shear stress coupling between adjacent grid cells (e.g., Greve and Blatter, 2009). The computations for the ice dynamics are all performed on an Arakawa A-Grid (Arakawa and Lamb, 1977), treating model variables, e.g., bedrock elevation, ice thickness and velocity, as located at the grid center.

With the surface elevation $S$ (Eq. 17) and $S=B+W+H$ the geometry of the ice model is directly coupled to the hydrology model by the basal water layer $W$ (Eqs. 4 and 5). The basal water layer, which is situated between bedrock and ice base, can gain a certain thickness and thus lift the overlaying ice by this amount. Additionally, the balance water flux $\phi$ 
(Eq. 16), provided by the hydrology model, affects the basal sliding, which is elaborated upon in the following section.

The boundary condition at the ice base for the calculation of the basal ice velocity $\boldsymbol{v}_{\mathrm{b}}$ is given by the sliding-law relationship $\tau_{\mathrm{b}}=\beta^{2} \boldsymbol{v}_{\mathrm{b}}$, where $\beta^{2}$ is defined as a Weertman type sliding law (e.g., Cuffey and Paterson, 2010):

$\beta^{2}=C^{\frac{1}{m}}\left|\boldsymbol{\tau}_{\mathrm{b}}\right|^{1-\frac{1}{m}}$

where $m=1 / 3$ is the sliding coefficient and $C$ is the sliding rate. To reduce the nonlinearity of the SSA momentum balance (Eq. 17) the basal shear stress $\boldsymbol{\tau}_{\mathrm{b}}$ in Eq. (18) can be expressed by the approximation (e.g., Cuffey and Paterson, 2010)

$\boldsymbol{\tau}_{\mathrm{b}}=-\rho_{\mathrm{i}} g H \nabla S$.

Typical values for $\beta^{2}$ are the range of $\beta^{2}=0$ for a stress-free ice base (e.g., above subglacial lakes and for ice shelves) and $\beta^{2} \approx 25000 \mathrm{Pam}^{-1}$ a (typical ice velocity of $v=4 \mathrm{~m} \mathrm{a}^{-1}$ at a basal shear stress of $\tau_{\mathrm{b}}=100 \mathrm{kPa}, \tau_{\mathrm{b}}$ by Cuffey and Paterson, 2010). We treat all grid cells where the basal water layer thickness exceeds one meter as subglacial lakes and fix $\beta^{2}$ to zero there.

To parameterize the hydrology-dependent basal sliding, a relevant coupling variable would be the basal water pressure (e.g., Clarke, 2005; Cuffey and Paterson, 2010; Schoof, 2010), which is not provided by our hydrology approach. Similar balance-flux applications (e.g., Le Brocq et al., 2009) assume a laminar water flow and then couple the sliding to the steady-state water-film depth. We want to avoid further assumptions about the type of the distributed water flow regime and introduce a simple physically plausible correlation of the sliding rate $C(\phi)$ (Eq. 18) and the subglacial water flux $\phi$ (Eq. 16):

$C(\phi)=C_{0} \exp ^{-m \frac{\phi}{\phi_{0}}}$,

with $C_{0}=10^{7} \mathrm{Pam}^{-1 / 3} \mathrm{~s}^{1 / 3}$ (Pattyn et al., 2013) and the reference flux $\phi_{0}$ scaling this correlation. Consequently, an increased flux $\phi$ implies a smaller sliding rate $C(\phi)$ and thus an enhanced slipperiness, which decreases $\beta^{2}$ to a possible minimum of zero. A reasonable reference flux $\phi_{0}$ can be obtained by adapting it to observed ice surface velocities. In general, basal water fluxes for Antarctica elude direct observation. They can be indirectly estimated by the observation of ice surface elevation changes resulting from filling and discharge of subglacial lakes. Deduced volume fluxes vary from about 1 to $20 \mathrm{~m}^{3} \mathrm{~s}^{-1}$ (Gray et al., 2005; Fricker and Scambos, 2009), in some cases up to $40 \mathrm{~m}^{3} \mathrm{~s}^{-1}$ (Wingham et al., 2006; Fricker et al., 2007), and even peak values of about $300 \mathrm{~m}^{3} \mathrm{~s}^{-1}$ (e.g., Carter and Fricker, 2012) are estimated.

The relation between deviatoric stress $\tau$ and strain rate $\dot{\epsilon}$ is given by Glen's flow law to $\dot{\epsilon}=A(T) \tau^{n}$ with $n=3$ and a temperature-dependent rate factor $A(T)$. The evolution of
Table 1. Schematic overview of the coupling between hydrology and ice model for all coupled experiments.

\begin{tabular}{|c|c|c|c|c|}
\hline & $\begin{array}{l}\text { Hydrology } \\
\text { model }\end{array}$ & Hydrology & Coupling & Ice \\
\hline BW & $\begin{array}{l}\text { Balanced } \\
\text { water layer } \\
\text { concept }\end{array}$ & Water layer & & $\begin{array}{l}\text { Geometry } \\
\text { Melting } \\
\text { Sliding }\end{array}$ \\
\hline BWF & $\begin{array}{l}\text { Balanced } \\
\text { water layer } \\
\text { concept }\end{array}$ & $\begin{array}{l}\text { Water layer } \\
\text { Water flux }\end{array}$ & & $\begin{array}{l}\text { Geometry } \\
\text { Melting } \\
\text { Sliding }\end{array}$ \\
\hline $\mathrm{BF}, \mathrm{BF}^{+}$ & $\begin{array}{l}\text { Balance } \\
\text { flux } \\
\text { concept }\end{array}$ & Water flux & & $\begin{array}{l}\text { Melting } \\
\text { Sliding }\end{array}$ \\
\hline
\end{tabular}

the ice thickness $H$ follows from the continuity equation

$\frac{\partial H}{\partial t}=-\operatorname{div}\left(H \bar{v}_{\mathrm{i}}\right)+A_{\mathrm{S}}-M$,

where $\bar{v}_{\mathrm{i}}$ is the vertically averaged ice velocity, $A_{\mathrm{S}}$ is the surface accumulation rate and $M$ is the basal melt rate.

The ice temperature is calculated by solving the energy conservation equation and neglecting the horizontal diffusion for 21 terrain-following vertical layers, which become thinner towards the ice base. It is forced with the atmospheric temperature as a Dirichlet boundary condition at the surface and the geothermal heat flux as a Neumann boundary condition at the ice base. The basal melt rate $M$ is given by (e.g., Pattyn, 2003)

$M=\frac{1}{L \rho_{\text {ice }}}\left(k \frac{\partial T_{\mathrm{b}}^{*}}{\partial z}+G+\boldsymbol{\tau}_{\mathrm{b}} \boldsymbol{v}_{\mathrm{b}}\right)$,

where $L=335 \mathrm{~kJ} \mathrm{~kg}^{-1}$ is the specific latent heat of fusion and $k=2.1 \mathrm{~W} \mathrm{~m}^{-1} \mathrm{~K}^{-1}$ the thermal conductivity for ice, $T_{\mathrm{b}}^{*}$ is the basal ice temperature corrected for pressure melting and $G$ is the geothermal heat flux. The last term in Eq. (22) is the contribution of basal frictional heating, which can dominate the melting at the ice base in areas of faster ice flow (e.g., Joughin et al., 2004; Cuffey and Paterson, 2010) and can be ignored in areas where the ice is frozen to the bedrock.

\section{Experiments and results}

In the present study we use a rectangular model domain on the scale of $60 \mathrm{~km} \times 200 \mathrm{~km}$ with a grid resolution of $2 \mathrm{~km}$ (Fig. 2a). Closed free-slip boundaries are defined at the lateral ice sheet margins and the ice divide. At the ice sheet front a free-flux boundary allows mass loss, which could be interpreted as calving into an adjacent ocean. In experiments where a hydrological model is applied (Table 1), the ice sheet front is treated as an open and the lateral margins and the ice divide as closed hydrological boundaries. 
(a)

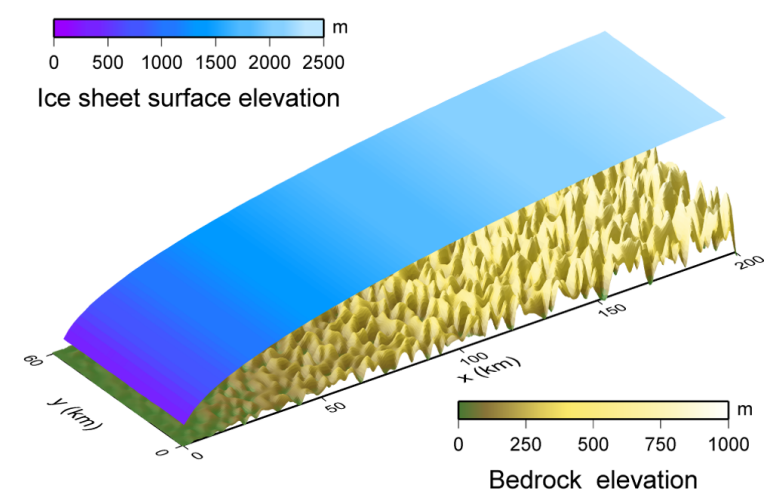

(b)

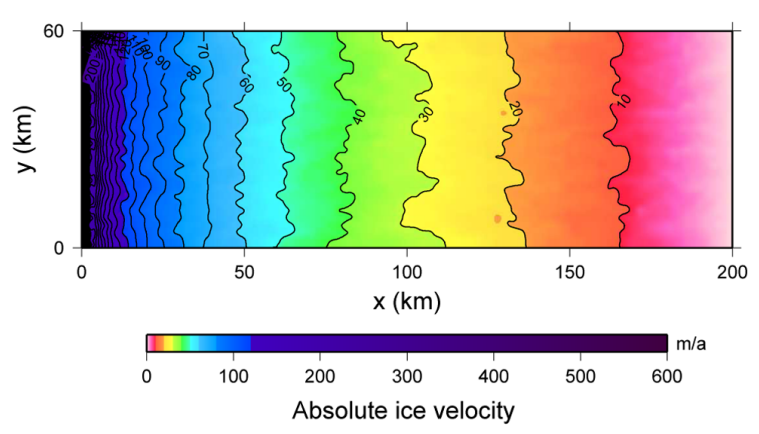

(c)

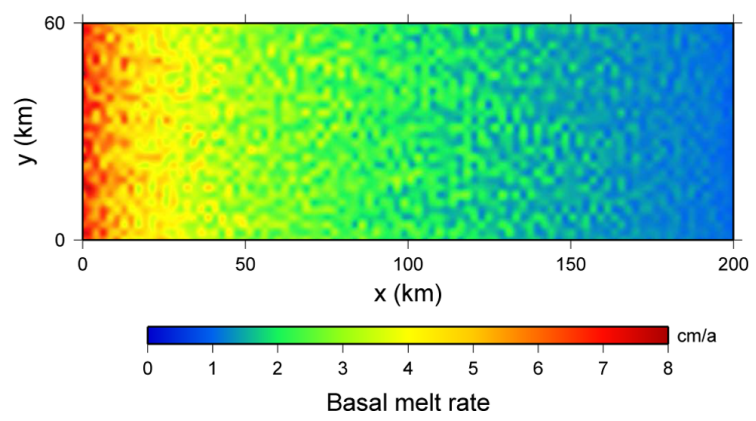

Fig. 2. Control run (CR): (a) model domain with mountainous bedrock and steady-state ice sheet topography, (b) absolute ice velocities and (c) basal melt rates.

The bedrock consists of randomly distributed peaks with a linear increasing random amplitude up to $1 \mathrm{~km}$. This artificial topography with mountains and troughs roughly mimics typical characteristics of observations, e.g., in the Gamburtsev Mountains region in East Antarctica (Bell et al., 2011) or the Ellsworth Mountains (Woodward et al., 2010) in West Antarctica. Although the used terrain generation algorithm overestimates the number of enclosed bedrock basins compared to observations (e.g., Anderson and Anderson, 2010), it is well suitable to demonstrate the balanced water layer concept.
In this study we omit the glacial isostatic adjustment and apply a constant bedrock elevation $B$ for simplicity (Eq. 4). All experiments are carried out with the same bedrock topography to guarantee comparability and are run for $20000 \mathrm{yr}$ until both the ice dynamics and the hydrological system are in a steady state. A time step of $\Delta t=1 \mathrm{yr}$ guarantees a compliance with the Courant-Friedrich-Levy criterium $|\boldsymbol{v}| \Delta t / \Delta x \leq 1$.

The ice surface temperature $T_{\mathrm{s}}$ is set to $-10^{\circ} \mathrm{C}$, the accumulation rate $A_{S}$ is $0.5 \mathrm{~m} \mathrm{a}^{-1}$, and the geothermal heat flux $G$ is $0.15 \mathrm{~W} \mathrm{~m}^{-2}$ all over the model domain. Compared to measurements in Antarctica, we chose relatively high surface temperature (Comiso, 2000) and accumulation rate (Arthern et al., 2006). Also the chosen geothermal heat flux is in the upper range of the estimated spectrum for Antarctica (Shapiro and Ritzwoller, 2004; Maule et al., 2005), which simply leads to higher melting rates and thus to a faster convergence of the basal hydraulic system in our model runs.

\subsection{CR - control run without hydrology}

All experiments start with the same steady-state ice sheet (Fig. 2a), which we call the control run (CR). The total accumulation balances the mass loss at the ice sheet front at an ice volume of $17001 \mathrm{~km}^{3}$. The ice thickness of this parabolic ice sheet varies from $2294 \mathrm{~m}$ at the ice divide to $263 \mathrm{~m}$ at the ice sheet front, where the ice velocity increases up to $535 \mathrm{~m} \mathrm{a}^{-1}$. The variations of the ice velocity show clearly the influence of the mountainous bedrock (Fig. 2b). The melt rate (Eq. 22) is taken into account for the calculation of the ice thickness evolution (Eq. 21) and the vertical ice velocity. However, no subglacial hydrology model has been applied. Accordingly, there is no flux-sliding coupling (Eq. 20) incorporated and $C(\phi)=C_{0}$. Figure 2c shows the melt rates, which are lowest in the interior of the ice sheet, where the ice velocities are low and thus the melting is governed by the geothermal heat flux (Eq. 22). In the vicinity of the ice divide they range from about $1 \mathrm{~mm} \mathrm{a}^{-1}$ to maximum values of $15 \mathrm{~mm} \mathrm{a}^{-1}$ in deep bedrock troughs, where the ice thickness reaches its maximum and thus insulates the ice sheets base best from the surface temperature. Towards the ice sheet front the ice velocities increase and the melting is clearly dominated by frictional heating, reaching values up to $76 \mathrm{~mm} \mathrm{a}^{-1}$. The modeled melt rates are higher than estimates for the Antarctic Ice Sheet (e.g., Carter et al., 2009; Pattyn, 2010), due to the chosen thermal boundary conditions for a faster convergence of the hydraulic system in the next experiments.

\subsection{BW - balanced water layer concept lake-sliding coupling}

Starting from the control run, we apply the balanced water layer concept with $C(\phi)=C_{0}$. As a consequence melt water is able to accumulate in hollows of the hydraulic potential and starts to form subglacial lakes. We set the convergence 


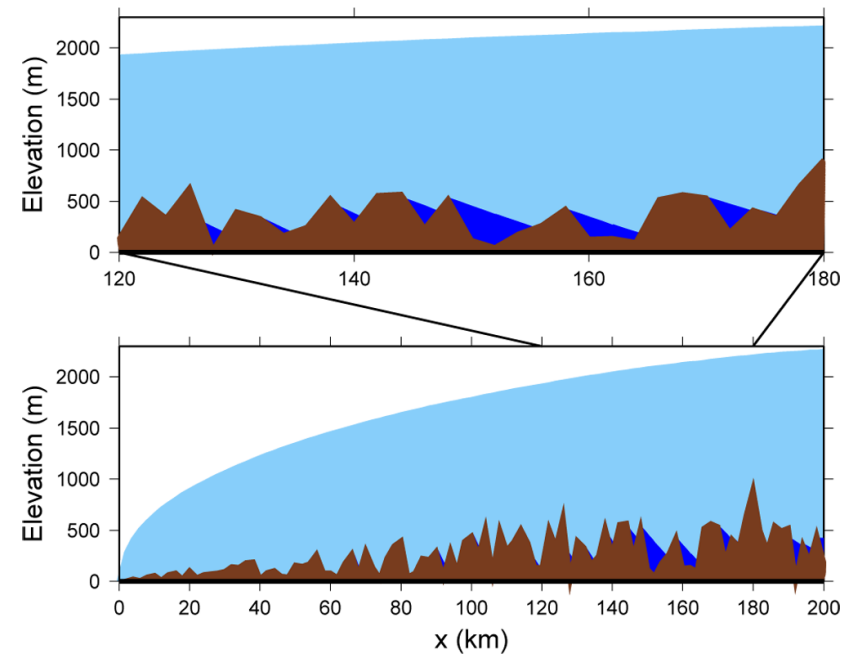

Fig. 3. Exp. BW: profile of the ice sheet at $y=22 \mathrm{~km}$, showing several subglacial lakes and their inclined surfaces due to the ice thickness gradient.

parameters $\Delta W^{\text {(threshold) }}=10^{-10} \mathrm{~m}$ and $\varepsilon=0.5$, which is a good compromise between fast convergence and reasonable accuracy. The hydraulic system reaches a steady state after running the model for $20000 \mathrm{yr}$, meaning all subglacial hollows are filled and the entire generated melt water of $0.288 \mathrm{~km}^{3} \mathrm{a}^{-1}$ is leaving the model domain at the ice sheet front. Grid cells where the basal water layer thickness exceeds one meter are defined as subglacial lakes. Above these lakes we assume a stress-free ice base. In total we find 266 subglacial lakes covering $2256 \mathrm{~km}^{2}$ with a water volume of $372 \mathrm{~km}^{3}$. The percentage of the bed covered with subglacial lakes is $18.8 \%$ for the model domain. Compared to estimates of the lake coverage for the whole Antartic continent with $\approx 0.4 \%\left(\approx 50000 \mathrm{~km}^{2}\right.$ of known lakes, Wright and Siegert, 2011) this number is high. The discrepancy can be explained by the topography we use. It is meant to loosely resemble particular Antarctic areas with a mountainous bedrock (and even for these it overestimates the number of enclosed basins) and is thus not representative for the whole Antarctic continent. Fitting to observations the majority of the lakes in BW is situated close to the ice divide, where the ice surface gradient is low and the bedrock elevation gradients are high (Tabacco et al., 2006). The surfaces of the lakes are inclined due to the basal pressure conditions resulting from the ice thickness gradients over the lakes (Fig. 3). This corresponds to observations in Antarctica where lake surfaces reflect the ice surface slope with an amplification of a factor of nine (e.g., Bell et al., 2011). The largest lakes reach up to $100 \mathrm{~km}^{2}$ extent and water depths up to $636 \mathrm{~m}$ (Fig. 4a). The ice velocity in BW shows clear evidence of spatial variations in basal stresses, as there are many spots with an enhanced velocity in correlation with the location of subglacial lakes (Fig. 4b), and the total ice volume decreases to $16443 \mathrm{~km}^{3}$, which will be discussed in Sect. 5 .

\subsection{BWF - balanced water layer concept lake-and flux-sliding coupling}

In a second BWF experiment we again apply the balanced water layer concept but extend BW by coupling the basal water flux (Eq. 16) to the basal sliding rate (Eq. 20). We set the reference flux to $\phi_{0}=10^{4} \mathrm{~m}^{2} \mathrm{a}^{-1}$, which is just an example to illustrate the flux-sliding interaction. The generated melt water amounts to $0.286 \mathrm{~km}^{3} \mathrm{a}^{-1}$. Figure $5 \mathrm{a}$ shows the basal balance water flux with a maximum of $19794 \mathrm{~m}^{2} \mathrm{a}^{-1}$, forming a branching stream system. All the melt water from upstream areas flows through plenty of subglacial lakes towards the ice sheet front. The feedback of the flux-sliding coupling to the distribution and water volume of the subglacial lakes is minimal. In comparison to BW their total volume diminishes by only $2.2 \%$ to $364 \mathrm{~km}^{3}$. As a consequence of the flux-sliding coupling, ice streams evolve above the very focused subglacial water streams. They are about $4 \mathrm{~km}$ wide and move about $20 \mathrm{~m} \mathrm{a}^{-1}(\approx 50 \%)$ faster than the adjacent ice (Fig. 5b). Arteries of increased ice velocities reach also far upstream into the ice sheet where velocity differences to BW of up to $5 \mathrm{~m} \mathrm{a}^{-1}(\approx 25 \%)$ can be seen locally. The ice velocity reaches its maximum with $595 \mathrm{~m} \mathrm{a}^{-1}$ at the ice sheet front. Consequently, the total ice volume diminishes to $15769 \mathrm{~km}^{3}$.

\section{4 $\mathrm{BF}$ and $\mathrm{BF}^{+}$- balance flux concept flux-sliding coupling}

We perform two more benchmark experiments, where we apply the Budd and Warner (1996) balance flux scheme with the same flux-sliding coupling as in BWF. For the calculation of the balance flux we use the hydraulic potential (Eq. 4) with $W=0$, because the balance flux scheme does not provide the accumulation of water within subglacial hollows.

In experiment $\mathrm{BF} 0.307 \mathrm{~km}^{3} \mathrm{a}^{-1}$ melt water is produced. But only a constant water flux of $0.166 \mathrm{~km}^{3} \mathrm{a}^{-1}(54 \%)$ leaves the model domain at the ice sheet front, while the significant amount of $0.141 \mathrm{~km}^{3} \mathrm{a}^{-1}(46 \%)$ is lost in hollows of the hydraulic potential. The ice volume diminishes as a consequence of the flux-sliding coupling to $16722 \mathrm{~km}^{3}$.

We overcome the limitation of $\mathrm{BF}_{\text {in }} \mathrm{BF}^{+}$by modifying the hydraulic potential before the calculation of the balance flux. We fill up all hollows in the hydraulic potential and slightly taper the resulting flats in the direction of their previously identified discharge point. In this way we guarantee flux conservation (comparable with, e.g., Le Brocq et al., 2009), and the entire generated melt water of $0.312 \mathrm{~km}^{3} \mathrm{a}^{-1}$ leaves the model domain at the ice sheet front. The fluxsliding coupling causes a decrease of the ice volume to $16224 \mathrm{~km}^{3}$. 
(a)

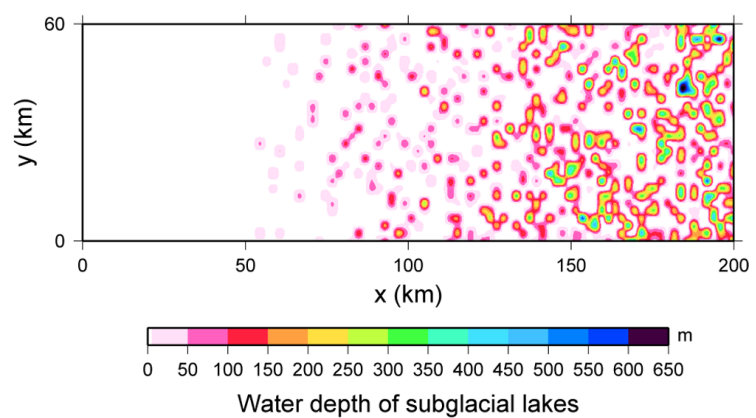

(b)

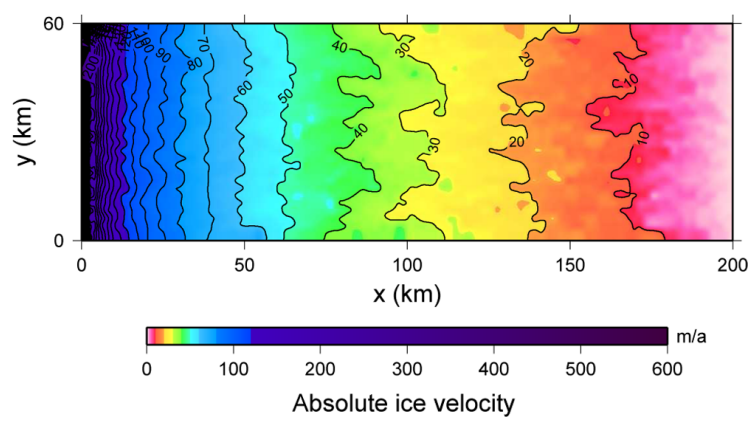

Fig. 4. Exp. BW: (a) water depths of subglacial lakes and (b) absolute ice velocities.

\section{Discussion}

The comparison of the subglacial water balance for all experiments is shown in Fig. 6a. In BF $46 \%$ of the generated melt water is lost inside the model domain. This confirms the necessity of the preceding modification of the hydraulic potential in $\mathrm{BF}^{+}$to obtain reasonable results with that method, which means an additional computational effort. This extra effort is not required for the balance water layer concept, which is water volume conserving on any hydraulic potential. Additionally, the fluxes into hollows of the hydraulic potential and over the model margin show a time-dependent behavior in BW \& BWF. Both start with the same values as $\mathrm{BF}$. Then the flux into hollows of the hydraulic potential decreases as these slowly fill up. Simultaneously the flux over the model margin increases. The small steps in the time series of the fluxes indicate the time when single hollows are filled, and thus the entire melt water produced in their upstream catchment area starts contributing to downstream areas and the flux over the model margin. Once all hollows are filled, the entire generated melt water is transported through them and contributes to the flux over the model margin as in $\mathrm{BF}^{+}$. So the balanced water layer concept is able to describe the transitional behavior of the hydraulic system between $\mathrm{BF}$ and $\mathrm{BF}^{+}$.

The differences of the absolute ice velocity between the experiments and the control run reveal the influence of the (a)

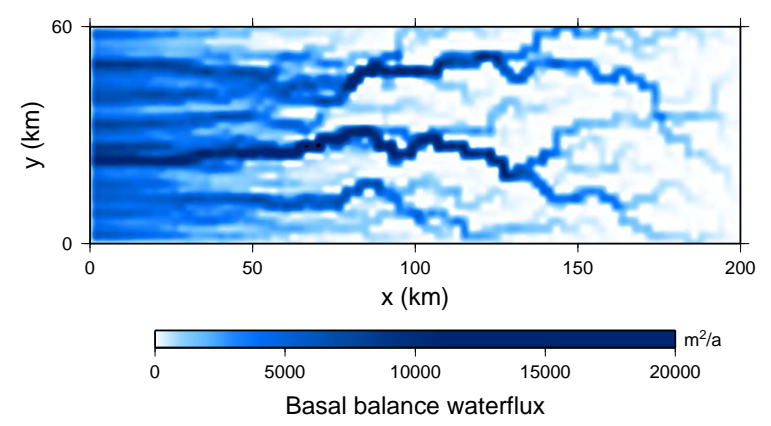

(b)

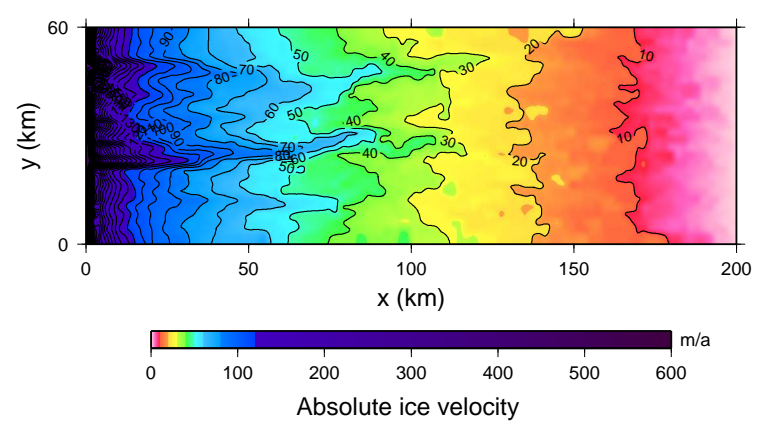

Fig. 5. Exp. BWF: (a) basal balance water flux and (b) absolute ice velocities.

basal hydraulic system on ice dynamics and mass balance. BW indicates that ice velocities above subglacial lakes are increased, while downstream of the lakes the velocity decreases again (Fig. 7a). This effect is consistent with observations of the surface velocity field based on radar interferometry, e.g., for Lake Vostok by Kwok et al. (2000), and could be reproduced by models for a single lake (Pattyn et al., 2004; Thoma et al., 2010, 2012). Although the velocity increase of the ice in BW is only a local phenomenon above subglacial lakes, they do have an impact on the mass balance of the entire ice sheet. Figure $6 \mathrm{~b}$ shows the temporal development of the total ice and lake volume for the different experiments (summary in Table 2). Compared to the control run, we find for BW an ice loss of $558 \mathrm{~km}^{3} \mathrm{a}^{-1}(-3.3 \%)$. Taking into consideration the stored subglacial water volume of $372 \mathrm{~km}^{3}$, which replaced the corresponding ice volume, there is still an overall volume $\left(V_{\text {ice }}+V_{\text {water }}\right)$ loss of $186 \mathrm{~km}^{3}(-1.1 \%)$. In comparison to the direct mass loss caused by basal melting of $0.288 \mathrm{~km}^{3} \mathrm{a}^{-1}$, the indirect contribution of the accumulated basal water to the mass balance of the ice sheet is large.

Due to the flux-sliding coupling the ice velocity field in BWF shows also the imprint of the basal water fluxes (Fig. 7b). Ice streams drain mass from the central areas and thus cause a thinning and flattening of the ice sheet. That again results in a lower basal shear stress (Eq. 19), which is driven by the ice surface gradient. Consequently, less hydrologically active areas beside the ice streams show 
(a)

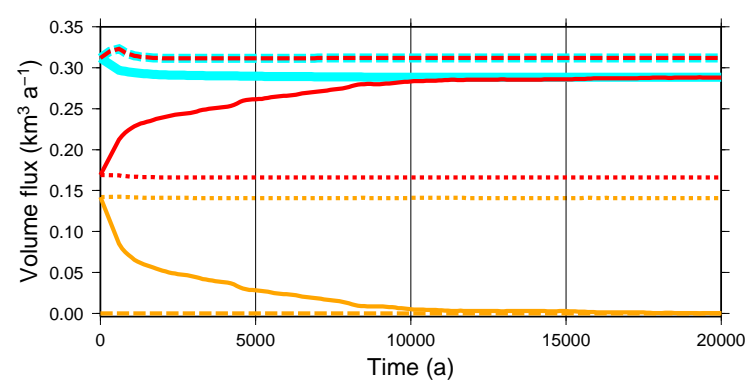

(b)

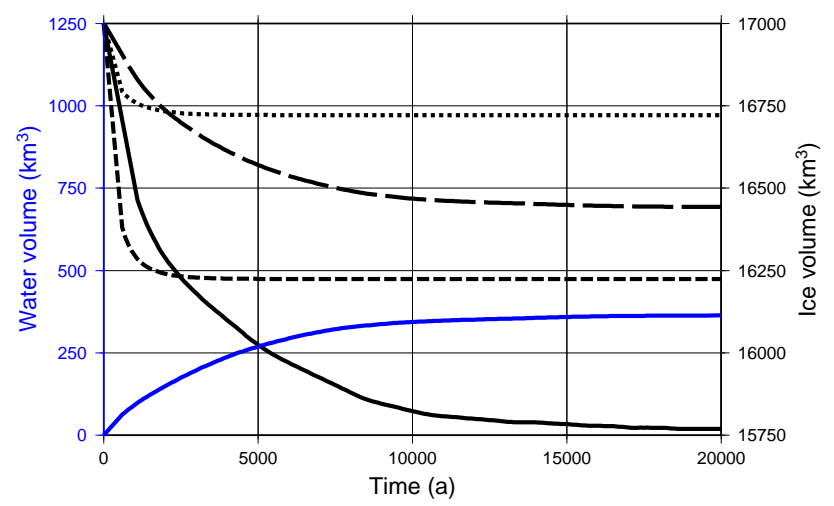

\begin{tabular}{|lllll|}
\hline & $\mathrm{BW}$ & $\mathrm{BWF}$ & $\mathrm{BF}$ & $\mathrm{BF}^{+}$ \\
Melt water & & & $\ldots .$. & --- \\
Flux over model margin & - & - & $\ldots .$. & -- \\
Flux into lakes / hollows & - & - & $\ldots .$. & --- \\
Ice volume & - & - & $\ldots .$. & --- \\
Subglacial lakes volume & - & - & & \\
\hline
\end{tabular}

Fig. 6. (a) Subglacial water balance and (b) ice and subglacial lake volume for all experiments. (Experiments with very similar results share one line style.)

Table 2. Ice volume, change of ice volume compared to the control run $(\mathrm{CR})$ and stored subglacial water volume for all experiments.

\begin{tabular}{lccc}
\hline & $V_{\text {ice }}\left(\mathrm{km}^{3}\right)$ & $\Delta V_{\text {ice }}(\%)$ & $V_{\text {water }}\left(\mathrm{km}^{3}\right)$ \\
\hline $\mathrm{CR}$ & 17001 & & 0 \\
$\mathrm{BW}$ & 16443 & -3.3 & 372 \\
$\mathrm{BWF}$ & 15769 & -7.2 & 364 \\
$\mathrm{BF}$ & 16722 & -1.6 & 0 \\
$\mathrm{BF}^{+}$ & 16224 & -4.6 & 0 \\
\hline
\end{tabular}

significantly lower ice velocities and therefore contribute to a stabilization of the ice sheet. Nevertheless, the mass balance of BWF compared to the control run is negative, since the ice volume is reduced by $1232 \mathrm{~km}^{3}(-7.2 \%)$. The overall volume loss amounts to $868 \mathrm{~km}^{3}(-5.1 \%)$. (a)

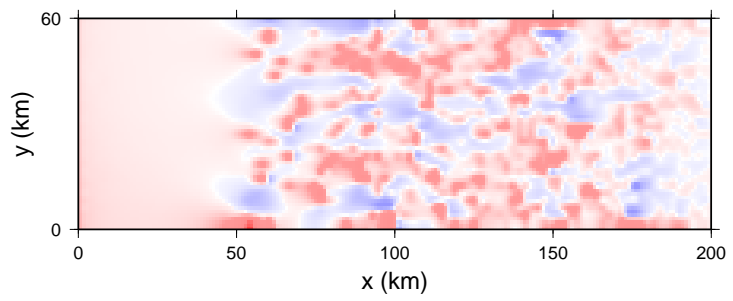

(b)

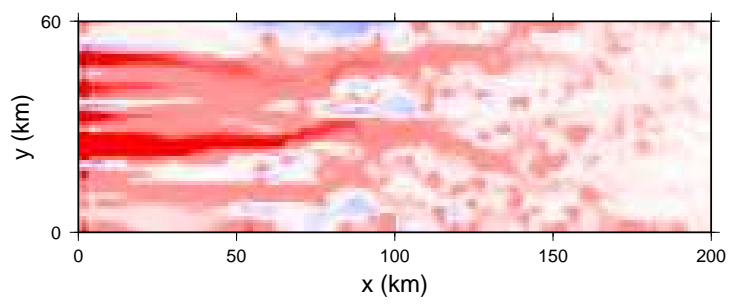

(c)

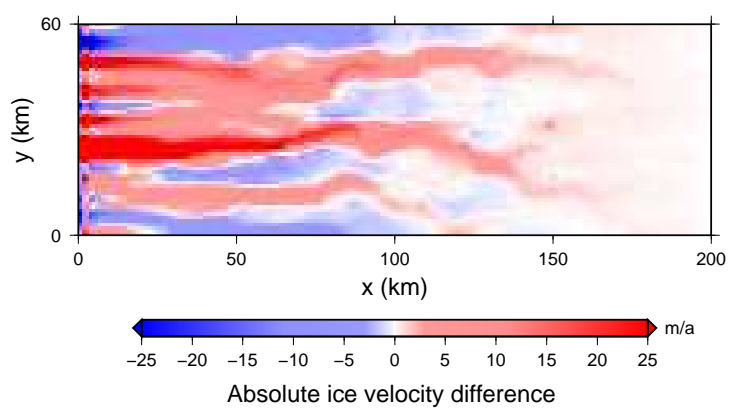

Fig. 7. Absolute ice velocity variations of (a) BW, (b) BWF and (c) $\mathrm{BF}^{+}$compared to the control run $(\mathrm{CR})$. Values are truncated at $\pm 25 \mathrm{~m} \mathrm{a}^{-1}$.

In $\mathrm{BF}$ only $54 \%$ of the melt water reaches the model margin; thus the effect of the flux-sliding coupling is relatively small and the ice volume solely decreases by $279 \mathrm{~km}^{3}$ $(-1.6 \%)$. In $\mathrm{BF}^{+}$the ice velocity field shows the influence of the basal water fluxes (Fig. 7c) just as BWF. However, since this approach is not capable of storing melt water, the impact of the subglacial lakes on ice dynamics is missing. As a consequence the ice volume diminishes for the amount of $777 \mathrm{~km}^{3}(-4.6 \%)$ only.

In subsequent studies the potential of the new concept to analyze the dynamic evolution and interaction of lakes and subglacial water streams would allow one to estimate the impact of changed forcing parameters of the ice model on the basal hydrological system. So climate changes - e.g., variations of the accumulation rate and surface temperature affect the ice thickness and thus the hydraulic potential at the ice base, which can redirect subglacial water streams at large scales (e.g., Anandakrishnan and Alley, 1997; Le Brocq et al., 2006; Wright et al., 2008) or cause subglacial lake 
drainage (e.g., Evatt et al., 2006; Wingham et al., 2006; Scambos et al., 2011; Carter and Fricker, 2012).

\section{Conclusion}

The introduced balanced water layer concept for subglacial hydrology takes a different approach than existing balance flux schemes (Quinn et al., 1991; Budd and Warner, 1996; Tarboton, 1997). It yields a mass conserving balance flux on any topography and is able to accumulate water in subglacial hollows, where subglacial lakes can develop. The balanced water layer scheme can be coupled to any ice model, operating in shallow-ice, shallow-shelf or higher-order approximation on numerical Arakawa A- or C-grids. The water layer thickness modifies the geometry by lifting the ice base, while water fluxes can be parameterized to increase the basal ice velocities. Above subglacial lakes the basal shear stress of the ice vanishes completely. The provided dynamic generation of subglacial lakes and the self-organization of subglacial water drainage systems combined with a flux-friction coupling improve the modeled dynamics of glacial systems. Therefore, our concept has the potential for better prediction of the mass export of large ice sheets under the influence of climate warming, and thus their contribution to future global sea level rise.

Acknowledgements. This work was funded by the Helmholtz Climate Initiative REKLIM (Regional Climate Change), a joint research project of the Helmholtz Association of German research centres (HGF), and through the DFG research grant MA3347/2-1. The authors wish to thank Christoph Mayer for his collaboration in this project, Angelika Humbert for fruitful discussions, Conor Purcell for proof reading as well as Basile de Fleurian and three anonymous reviewers for their constructive comments which improved the manuscript.

Edited by: E. Larour

\section{References}

Alley, R. B.: Towards a hydrological model for computerized icesheet simulations, Hydrol. Processes, 10, 649-660, 1996.

Alley, R., Blankenship, D., Bentley, C., and Rooney, S.: Deformation of till beneath ice stream B, West Antarctica, Nature, 322, 57-59, 1986.

Anandakrishnan, S. and Alley, R. B.: Stagnation of Ice Stream C, West Antarctica by water piracy, Geophys. Res. Lett., 24, 265268, 1997.

Anderson, R. S. and Anderson, S. P.: Geomorphology: the mechanics and chemistry of landscapes, Cambridge University Press, 2010.

Arakawa, A. and Lamb, V. R.: Methods of computational physics, vol. 17, Academic Press, 1977.

Arthern, R. J., Winebrenner, D. P., and Vaughan, D. G.: Antarctic snow accumulation mapped using polarization of $4.3-\mathrm{cm}$ wavelength microwave emission, J. Geophys. Res. Atmos., 111, D06107 doi:10.1029/2004JD005667, 2006.
Bell, R. E., Studinger, M., Shuman, C. A., Fahnestock, M. A., and Joughin, I.: Large subglacial lakes in East Antarctica at the onset of fast-flowing ice streams, Nature, 445, 904-907, 2007.

Bell, R. E., Ferraccioli, F., Creyts, T. T., Braaten, D., Corr, H., Das, I., Damaske, D., Frearson, N., Jordan, T., Rose, K., Studinger, M., and Wolovick, M.: Widespread persistent thickening of the East Antarctic Ice Sheet by freezing from the base, Science, 331, 1592-1595, 2011.

Budd, W. and Jenssen, D.: Numerical Modelling of the Large-Scale Basal Water Flux under the West Antarctic Ice Sheet, in: Dynamics of the West Antarctic Ice Sheet, edited by: Veen, C. and Oerlemans, J., vol. 4 of Glaciology and Quaternary Geology, 293-320, Springer Netherlands, 1987.

Budd, W. F. and Warner, R. C.: A computer scheme for rapid calculations of balance-flux distributions, Ann. Glaciol., 23, 21-27, 1996.

Carter, S. and Fricker, H.: The supply of subglacial meltwater to the grounding line of the Siple Coast, West Antarctica, Ann. Glaciol., 53, 267-280, 2012.

Carter, S. P., Blankenship, D. D., Young, D. A., and Holt, J. W.: Using radar-sounding data to identify the distribution and sources of subglacial water: application to Dome C, East Antarctica, J. Glaciol., 55, 1025-1040, 2009.

Clarke, G. K.: Subglacial processes, Annu. Rev. Earth Planet. Sci., 33, 247-276, 2005.

Comiso, J. C.: Variability and trends in Antarctic surface temperatures from in situ and satellite infrared measurements, J. Climate, 13, 1674-1696, 2000.

Cuffey, K. M. and Paterson, W. S. B.: The Physics of Glaciers, Elsevier, Amsterdam, 4th Edn., 2010.

Determann, J., Thoma, M., Grosfeld, K., and Massmann, S.: Impact of ice-shelf basal melting on inland ice-sheet thickness: a model study, Ann. Glaciol., 53, 129-135, 2012.

Evatt, G., Fowler, A., Clark, C., and Hulton, N.: Subglacial floods beneath ice sheets, Phil. Trans. Roy. Soc. A, 364, 1769-1794, 2006.

Fretwell, P., Pritchard, H. D., Vaughan, D. G., Bamber, J. L., Barrand, N. E., Bell, R., Bianchi, C., Bingham, R. G., Blankenship, D. D., Casassa, G., Catania, G., Callens, D., Conway, H., Cook, A. J., Corr, H. F. J., Damaske, D., Damm, V., Ferraccioli, F., Forsberg, R., Fujita, S., Gim, Y., Gogineni, P., Griggs, J. A., Hindmarsh, R. C. A., Holmlund, P., Holt, J. W., Jacobel, R. W., Jenkins, A., Jokat, W., Jordan, T., King, E. C., Kohler, J., Krabill, W., Riger-Kusk, M., Langley, K. A., Leitchenkov, G., Leuschen, C., Luyendyk, B. P., Matsuoka, K., Mouginot, J., Nitsche, F. O., Nogi, Y., Nost, O. A., Popov, S. V., Rignot, E., Rippin, D. M., Rivera, A., Roberts, J., Ross, N., Siegert, M. J., Smith, A. M., Steinhage, D., Studinger, M., Sun, B., Tinto, B. K., Welch, B. C., Wilson, D., Young, D. A., Xiangbin, C., and Zirizzotti, A.: Bedmap2: improved ice bed, surface and thickness datasets for Antarctica, The Cryosphere, 7, 375-393, doi:10.5194/tc-7-3752013, 2013.

Fricker, H. A. and Scambos, T.: Connected subglacial lake activity on lower Mercer and Whillans Ice Streams, West Antarctica, 2003-2008, J. Glaciol., 55, 303-315, 2009.

Fricker, H. A., Scambos, T., Bindschadler, R., and Padman, L.: An active subglacial water system in west Antarctica mapped from space, Science, 315, 1544-1548, 2007. 
Fricker, H. A., Scambos, T., Carter, S., Davis, C., Haran, T., and Joughin, I.: Synthesizing multiple remote-sensing techniques for subglacial hydrologic mapping: application to a lake system beneath MacAyeal Ice Stream, West Antarctica, J. Glaciol., 56, 187-199, 2010.

Gray, L., Joughin, I., Tulaczyk, S., Spikes, V. B., Bindschadler, R., and Jezek, K.: Evidence for subglacial water transport in the West Antarctic Ice Sheet through three-dimensional satellite radar interferometry, Geophys. Res. Lett., 32, L03501, doi:10.1029/2004GL021387, 2005.

Greve, R. and Blatter, H.: Dynamics of ice sheets and glaciers, Springer Verlag, 2009.

Hewitt, I. J.: Modelling distributed and channelized subglacial drainage: the spacing of channels, J. Glaciol., 57, 302-314, 2011.

Hewitt, I. J., Schoof, C., and Werder, M. A.: Flotation and free surface flow in a model for subglacial drainage, Part 2. Channel flow, J. Fluid Mech., 702, 157-187, 2012.

IPCC: The physical science basis. Contribution of working group I to the fourth assessment report of the intergovernmental panel on climate change, in: Climate Change 2007, edited by: Solomon, S., Qin, D., Manning, M., Chen, Z., Marquis, M., Averyt, K. B., Tignor, M., and Miller, H. L., Cambridge University Press, Cambridge, United Kingdom and New York, NY, USA, p. 1009, 2007.

Joughin, I., Tulaczyk, S., MacAyeal, D. R., and Engelhardt, H.: Melting and freezing beneath the Ross ice streams, Antarctica, J. Glaciol., 50, 96-108, 2004.

Kwok, R., Siegert, M. J., and Carsey, F. D.: Ice motion over Lake Vostok, Antarctica: constraints on inferences regarding the accreted ice, J. Glaciol., 46, 689-694, 2000.

Le Brocq, A. M., Payne, A. J., and Siegert, M. J.: West Antarctic balance calculations: Impact of flux-routing algorithm, smoothing algorithm and topography, Comput. Geosci., 32, 1780-1795, 2006.

Le Brocq, A. M., Payne, A. J., Siegert, M. J., and Alley, R. B.: A subglacial water-flow model for West Antarctica, J. Glaciol., 55, 879-888, 2009.

Le Brocq, A. M., Payne, A. J., and Vieli, A.: An improved Antarctic dataset for high resolution numerical ice sheet models (ALBMAP v1), Earth Syst. Sci. Data, 2, 247-260, doi:10.5194/essd-2-247-2010, 2010.

Lliboutry, L.: General theory of subglacial cavitation and sliding of temperate glaciers, J. Glaciol., 7, 21-58, 1968.

MacAyeal, D. R.: Large-scale ice flow over a viscous basal sediment: Theory and application to ice stream B, Antarctica, J. Geophys. Res. 94, 4071-4087, 1989.

Maule, C. F., Purucker, M. E., Olsen, N., and Mosegaard, K.: Heat flux anomalies in Antarctica revealed by satellite magnetic data, Science, 309, 464-467, 2005.

Nye, J.: Water at the bed of a glacier, IASH Publ. 95 (Symposium at Cambridge 1969 - Hydrology of Glaciers), 477-489, 1973.

Pattyn, F.: A new three-dimensional higher-order thermomechanical ice sheet model: Basic sensitivity, ice stream development, and ice flow across subglacial lakes, J. Geophys. Res., 108, 2382, doi:10.1029/2002JB002329, 2003.

Pattyn, F.: Antarctic subglacial conditions inferred from a hybrid ice sheet/ice stream model, Earth Planet. Sci. Lett., 295, 451-461, 2010 .
Pattyn, F., de Smedt, B., and Souchez, R.: Influence of subglacial Vostok lake on the regional ice dynamics of the Antarctic ice sheet: a model study, J. Glaciol., 50, 583-589, 2004.

Pattyn, F., Perichon, L., Durand, G., Favier, L., Gagliardini, O., Hindmarsh, R. C. A., Zwinger, T., Albrecht, T., Cornford, S., Docquier, D., Fürst, J. J., Goldberg, D., Gudmundsson, G. H., Humbert, A., Hutten, M., Huybrechts, P., Jouvet, G., Kleiner, T., Larour, E., Martin, D., Morlighem, M., Payne, A. J., Pollard, D., Rúckamp, M., Rybak, O., Seroussi, H., Thoma, M., and Wilkens, N.: Grounding-line migration in plan-view marine icesheet models: results of the ice 2sea MISMIP3d intercomparison, J. Glaciol., 59, 410-422, 2013.

Quinn, P., Beven, K., Chevallier, P., and Planchon, O.: The prediction of hillslope flow paths for distributed hydrological modelling using digital terrain models, Hydrol. Processes, 5, 59-79, 1991.

Roethlisberger, H.: Water pressure in intra- and subglacial channels, J. Glaciol., 11, 177-203, 1972.

Scambos, T. A., Berthier, E., and Shuman, C. A.: The triggering of subglacial lake drainage during rapid glacier drawdown: Crane Glacier, Antarctic Peninsula, Ann. Glaciol., 52, 74-82, 2011.

Schoof, C.: Ice-sheet acceleration driven by melt supply variability, Nature, 468, 803-806, 2010.

Schoof, C., Hewitt, I. J., and Werder, M. A.: Flotation and free surface flow in a model for subglacial drainage, Part 1. Distributed drainage, J. Fluid Mech., 702, 126-156, 2012.

Shapiro, N. M. S. and Ritzwoller, M. H.: Inferring surface heat flux distributions guided by a global seismic model: particular application to Antarctica, Earth Planet. Sci. Lett., 223, 213-224, 2004

Shreve, R. L.: Movement of water in glaciers, J. Glaciol., 11, 205214, 1972.

Siegert, M. J., Carter, S., Tabacco, I. E., Popov, S., and Blankenship, D. D.: A revised inventory of Antarctic subglacial lakes, Antarct. Sci., 17, 453-460, 2005.

Smith, B. E., Fricker, H. A., Joughin, I. R., and Tulaczyk, S.: An inventory of active subglacial lakes in Antarctica detected by ICESat (2003-2008), J. Glaciol., 55, 573-595, 2009.

Tabacco, I. E., Cianfarra, P., Forieri, A., Salvini, F., and Zirizotti, A.: Physiography and tectonic setting of the subglacial lake district between Vostok and Belgica subglacial highlands (Antarctica), Geophys. J. Int., 165, 1029-1040, 2006.

Tarboton, D.: A new method for the determination of flow directions and upslope areas in grid digital elevation models, Water Resour. Res., 33, 309-319, 1997.

Thoma, M., Grosfeld, K., Mayer, C., and Pattyn, F.: Interaction between ice sheet dynamics and subglacial lake circulation: a coupled modelling approach, The Cryosphere, 4, 1-12, doi:10.5194/tc-4-1-2010, 2010.

Thoma, M., Grosfeld, K., Mayer, C., and Pattyn, F.: Ice-flow sensitivity to boundary processes: a coupled model study in the Vostok Subglacial Lake area, Antarctica, Ann. Glaciol., 53, 173-180, 2012.

Thoma, M., Grosfeld, K., Barbi, D., Determann, J., Goeller, S., Mayer, C., and Pattyn, F.: RIMBAY - a multi-physics 3-D ice-dynamics model for comprehensive applications: modeldescription and examples, Geosci. Model Dev. Discuss., 6, 32893347, doi:10.5194/gmdd-6-3289-2013, 2013.

Walder, J. S. and Fowler, A.: Channelized subglacial drainage over a deformable bed, J. Glaciol., 40, 3-15, 1994. 
Weertman, J.: General theory of water flow at the base of a glacier or ice sheet, Rev. Geophys. Space Phys., 10, 287-333, 1972.

Wingham, D. J., Siegert, M. J., Shepherd, A., and Muir, A. S.: Rapid discharge connects Antarctic subglacial lakes, Nature, 440, 1033-1036, 2006.

Woodward, J., Smith, A. M., Ross, N., Thoma, M., Corr, H., King, E. C., King, M., Grosfeld, K., Tranter, M., and Siegert, M.: Location for direct access to subglacial Lake Ellsworth: An assessment of geophysical data and modeling, Geophys. Res. Lett., 37 , L11501 doi:10.1029/2010GL042884, 2010.
Wright, A. and Siegert, M. J.: The identification and physiographical setting of Antarctic subglacial lakes: an update based on recent discoveries, in: Subglacial Antarctic Aquatic Environments, Geophys. Monogr. Ser., vol. 192, 9-26, AGU, Washington DC, 2011.

Wright, D. G., Siegert, M. J., Le Brocq, A. M., and Gore, D. B.: High sensitivity of subglacial hydrological pathways in Antarctica to small ice-sheet changes, Geophys. Res. Lett., 37, L17504, doi:10.1029/2008GL034937, 2008. 